\title{
18. celostátní archivní konference v Plzni
}

Nejen archiváři a archivářky z celé České republiky, ale i pozvaní zahraniční kolegové se opět sjeli na tradiční odbornou konferenci. Letos se jednalo v pořadí již o osmnácté setkání, které se tentokrát konalo v metropoli západních Čech, konkrétně ve dnech 23.-25. dubna 2019 v prostorách plzeňského Parkhotelu. Pod záštitou náměstka ministerstva vnitra Petra Mlsny, hejtmana Plzeňského kraje Josefa Bernarda, primátora statutárního města Plzně Martina Baxy a děkana Fakulty pedagogické Západočeské univerzity v Plzni Miroslava Randy konferenci uspořádala Česká archivní společnost, z. s., spolu s dalšími třemi institucemi. ${ }^{1}$

Plzeňská konference navázala na osvědčený model z předchozí konference v Liberci. Jednání byla rozdělena do paralelně probíhajících sekcí a bloků, které byly jednoznačně tematicky orientovány, přičemž se věnovaly dvěma základním okruhům. První, jenž nesl název Výroba nápojů v průmyslovém opojení, byl tradičně monotematický a souvisel s místem konání a odborným zaměřením pořadatelských archivů. Druhý tematický okruh, který probíhal v rámci paralelních sekcí, nabídl především př́íspěvky k aktuálním otázkám současného archivnictví.

V rámci okruhu Výroba nápojů v průmyslovém opojení byly předneseny téměř dvě desítky př́spěvků od českých archivářů, historiků a badatelů, rozdělených do pěti bloků. Úvodní blok z této sekce měl nápojový průmysl představit v širších historických souvislostech. Dále měli posluchači možnost v rámci tohoto okruhu vyslechnout referáty z oblastí, které se jmenovaly: Společenský rozměr piva a pivovarnictví, Majetková struktura a její proměna, Hospodářské souvislosti výroby a prodeje piva a Potravinářský průmysl v Plzni a okolí. Obecně lze říci, že většina příspěvků zaměřených na ústřední téma konference pojímala téma nápojů nejen z hledisek hospodářských, sociálních nebo kulturních dějin, ale také očima pracovníků v oblasti archivnictví a dějin správy. Posluchači měli možnost seznámit se např́iklad s problematikou legislativy spojené s pivem a lihovinami, s fenomény právovárečného měšt’anstva, potravinářských akciových společností, potravinářské výroby na moderních velkostatcích nebo stolních společností. Př́íspěvky často představovaly sondy do konkrétních archivních fondů a budou tak moci jako součást kolektivní monografie, která je pořadateli připravována, posloužit pro archivářky a archiváře zpracovávající stejné a podobné typy fondů. Bloky zaměřené na hlavní téma konference byly svědectvím o kompetenci archivářů v tomto směru. $\mathrm{O}$ tom, že tyto kompetence zasahují i do sousedních oblastí, jako je muzejnictví, svědčila prezentace krásně vypravené monografie Petra Jozy ze Státního okresního archivu v Děčíně o vývoji pivních lahví v Čechách.

Druhý okruh, jenž se věnoval aktuálním trendům a problémům, s nimiž se české archivnictví musí vyrovnávat, otevřela panelová diskuze na téma Koncepce českého archivnictví.

1 Organizátory 18. celostátní archivní konference byly Česká archivní společnost, z. s., Česká informační společnost, z. s. - pobočný spolek při Národním archivu, Státní oblastní archiv v Plzni a Archiv města Plzně. 
Kde jsme a kam směrujeme, které se zúčastnili jako moderující David Valůšek, předseda České archivní společnosti, z. s., a jako diskutující Petr Mlsna, náměstek ministerstva vnitra pro legislativu a archivnictví, Jiř́ Úlovec, ředitel odboru archivní správy ministerstva vnitra, Daniel Doležal, ředitel Státního oblastního archivu v Praze, a Karel Halla, vedoucí Státního okresního archivu v Chebu. Jednotliví členové panelu přednesli své pohledy na aktuální stav archivů v ČR a představili klíčová témata pro jejich fungování. Tyto oblasti zároveň hodnotili z hlediska aktuální činnosti archivů jako nejvíce problematické. Víceméně se shodli, že největší důraz je třeba klást na předarchivní péči (tj. na dohled nad elektronickými systémy spisových služeb, komunikaci s původci) a archivní zpracování fondů. Př́spěvky panelistů i diskutujících z pléna obsahovaly zejména reakce na nedávný „revoluční" vývoj v oblasti elektronizace tvorby a správy dokumentů u původců. Jediným „archivářským" tématem byly nové nástroje pro zpracování archiválií, přičemž se ukázalo, že část archivářské obce klíčový software vyvíjený archivní správou (ELZA) bez bližšího seznámení odmítá. Pro některé diskutující bylo znepokojivé zjištění, že se archivnictví čím dál více stává oborem zaměřeným především na správu informací, pro který jsou nezbytné digitální technologie. Panel se tak fakticky věnoval především aktuálním problémům, na dlouhodobé koncepce a vize směřování českého archivnictví bohužel nedošlo. Zejména z pohledu exekutivy významně zaznívalo vnímání české archivní sítě jako struktury správních úřadů tvořených státními archivy, v níž specializované a další nestátní archivy tvoří neorganický prvek.

Následující sekce z druhého okruhu měly podobný formát, tj. vždy svého moderátora a předem danou skupinu vystupujících. V rámci sekce s názvem Osobni údaje v archivnictví, GDPR a obecné trendy a překážky v akvizici a zpř́stupňováni archiválii, kterou moderovala Karolína Šimůnková z Národního archivu, diskutovali právníci zabývající se ochranou osobních údajů s archiváři nad konkrétními archiváliemi z hlediska jejich zpř́istupnění veřejnosti, přičemž diskuze ukázala, že v současné době v této oblasti existují dvě zcela protichůdné tendence. Za prvé je zde jasně patrný trend, který požaduje co nejširší svobodný př́stup k informacím. Druhý trend je zcela opačný a je pro něj charakteristická předimenzovaná ochrana osobních údajů, ale i dalších osobnostních práv a chráněných informací. Důraz byl kladen na možné právní následky zveřejnění archiválií poškozujících zájmy osob v nich zmíněných. Debata se týkala zejména archiválií vzniklých v období před rokem 1989 a spojených s činností bezpečnostních složek.

Sekce, která nesla název Kdo hledá, najde? Staré a nové cesty archivním labyrintem? a jejímž moderátorem byl Jan Edl ze Státního okresního archivu v Tachově, si primárně nekladla za cíl, aby mezi diskutujícími došlo $\mathrm{k}$ všeobecné názorové shodě nebo jasným závěrům. Naopak chtěla přimět účastníky, aby si především pokládali, inspirativně promýšleli a komentovali řadu současných palčivých otázek typu: Co od archivu očekává badatel? Co vše se skrývá pod pojmem péče o archiválie a jejich zpř́stupňování ve věku digitalizace? Jak moc má docházet k unifikaci prostřednictvím metodik či elektronického zpř́istupňování archivních dokumentů na webech jednotlivých archivů? A jaká je role archiváře ve věku digitalizace? $Z$ debaty především vyplynulo, že konzervativní i modernističtí archiváři mají hledat svorníky místo stavění valů. Badatelé si žádají zpřístupňování stále většího množství digitalizovaných archiválií a do nedávna i řady nevyužívaných archivních fondů. Tento fakt jen potvrzuje důležitou roli archivní práce jednotlivých archivních pracovníků. 
Vzděláváním archivár̊ỏ se zabývaly dvě sekce s názvem Vzdělávání archivárự a specialistů pro správu dokumentů a záznamů ve 21. století a Jak se stát archivářrem? První sekce moderovaná Mikulášem Čtvrtníkem ze Státního oblastního archivu v Praze byla zaměřena na další profesní vzdělávání archivárư. Diskuse poměrně jasně naznačila, že české archivnictví se potýká s nedostatkem kurzů pro další systematické vzdělávání archivářů. Bolestivým místem jsou agendy, které se týkají zejména práce s digitálními dokumenty či obecně s elektronickými systémy, a vzdělávání v oblasti předarchivní péče a práce se spisovými službami či jejich výstupy. Navazující sekce Jak se stát archivárem? moderovaná Stanislavem Bártou z Masarykovy univerzity se věnovala vysokoškolskému vzdělávání budoucích archivářů. Zde vyplynul na povrch určitý předěl mezi moderním a tradičním přístupem $\mathrm{k}$ archivářskému studiu. Tradičně chápané (na pomocné vědy historické orientované) vzdělávání se potýká s nedostatkem studentů majících zájem a schopných zvládnout náročnou výuku koncentrovanou hlavně na práci se staršími fondy, ale i s obtížnou uplatnitelností absolventů na trhu práce. Moderní trend akcentuje výuku kompetencí souvisejících se správou dokumentů $\mathrm{v}$ archivech, aktuálně zejména s digitalizací nástrojů používaných archivy i archiválií samotných, a s předarchivní péčí. Absolventi tohoto směru archivářského studia jsou dle závěrů předchozích sekcí v archivech poměrně žádaní. Problémem obou vzdělávacích směrů je obtížná dostupnost odpovídající praxe pro studenty, kteří se v rámci studijní praxe obvykle zabývají spíše pomocnými manuálními činnostmi.

$\mathrm{V}$ sekci s názvem Ve víru bezradnosti. Archivní výběr dokumentů z informačnich systémů veřejné správy, kterou moderoval Karel Koucký ze Státního okresního archivu v Kladně, se řešila problematika výběru archiválií z informačních systémů původců, jež stojí mimo segment elektronických systémů spisových služeb. Debata byla zaměřena na praktické př́iklady zejména z oblasti regionálního školství. Jejím výsledkem bylo konstatování, že pro oblast informačních systémů mimo segment spisových služeb jde vždy o řešení, které je pro daný systém jedinečné a nelze ho zobecnit. Nicméně mnohdy se $\mathrm{v}$ těchto systémech nacházejí velmi cenná data, a je proto žádoucí jejich získání pro trvalé archivní uložení.

Náplní sekce Okénko k sousedům - vybrané otázky ze zahraniční archivní praxe, kterou řídil Karel Halla ze Státního okresního archivu v Chebu, byla výměna informací vztahujících se ke konkrétním legislativním úpravám a zavedené archivní praxi v okolních zemích. $\mathrm{K}$ předem připraveným otázkám $\mathrm{z}$ této oblasti se $\mathrm{v}$ rámci diskuze vyjadřovali zástupci zahraničních archivních společností: předsedkyně Spolku rakouských archivářů Karin Sperl ze Zemského archivu Burgenlandu, generální ředitelka Bavorských státních archivů Margit Ksoll-Marcon, předseda Společnosti mad’arských archivářů István Kenyeres z budapešt'ského městského archivu a předseda Spolku německých archivářů Ralf Jacob z městského archivu v Halle.

V sekci Pomáhat nebo trestat? Kontroly a metodická pomoc původcům v otázkách spisové služby, kterou moderoval Milan Augustin ze Státního okresního archivu Karlovy Vary, diskutující sdíleli své zkušenosti s elektronickou spisovou službou svých původců. V rámci diskuse dospěli k závěru, že sankce obvykle neprinášśi výraznější nápravu nedostatků a že se jako účinnější jeví spíše metodická pomoc archivárưu. Problém, na nějž ovšem archivy narážejí, je skutečnost, že na jednoho archiváře připadá velké množství původců, takže není možné věnovat všem dostatečnou péči.

Sekce nazvaná Provenience a autenticita v postfaktickém věku: „, Originály“ ve 21. století byla moderována Zbyškem Stodůlkou z Národního archivu a Mikulášem Čtvrtníkem 
ze Státního oblastního archivu v Praze. Z hlediska debat o budoucnosti archivů přinesla mnoho podnětů, ale ani panelisté se neshodli na závěrech, jak se k předloženým otázkám postavit. Ústředním tématem sekce byla role archivů v současném světě jako institucí, které jsou schopné garantovat pravdivost obsahu uchovávaných materiálů. Otevřeny byly jednak otázky důvěryhodnosti elektronických dokumentů z hlediska jejich obsahu a to, jakým způsobem mají archivy postupovat, aby byla autenticita jimi spravovaných digitálních archiválií chápana stejně jako u analogových archiválií. $\mathrm{V}$ této souvislosti byl diskutován význam provenienčního principu a většina zúčastněných se klonila $\mathrm{k}$ potřebě jeho nové definice. V další části sekce se debata dotkla i délky ochranných lhůt, nebot'v současné době roste tlak na jejich zkracování či rušení, a důsledků, které to bude mít na zkracování lhůt pro odborné zpracování fondů.

V rámci sekce Mediální archivy, kterou řídila Katarína Gatialová z Národního filmového archivu, předestřeli pracovníci specializovaných archivů (Archiv České televize, Národní filmový archiv, Archiv Českého rozhlasu), jež mají ve svých sbírkách audio-vizuální prameny, své zkušenosti týkající se fyzické ochrany nosičů a jejich digitalizace.

Aktuální ediční projekty v oblasti textů, kartografických děl a fotografií byly představeny v rámci sekce Edice na stůl! Vydáváni archivnich pramenů úřední povahy k českým moderním a soudobým dějinám, kterou vedl Jan Bílek z Univerzity Hradec Králové. Diskuze se týkala především problémů, s nimiž se archiváři jako editoři nejčastěji potýkají.

Do nedávné minulosti českých, moravských a slezských archivu se obracela sekce Minulé a budouci horizonty českého archivnictví. Tato sekce sestávala $\mathrm{z}$ delších projevů jednotlivých vystupujících, jimiž byli Václav Ledvinka z Archivu hlavního města Prahy, Petr Hubka ze Státního oblastního archivu v Plzni a Karel Müller ze Zemského archivu v Opavě. Panelisté vzpomínali na svoji pracovní kariéru v archivech, která jim umožnila představit klíčové body ve vývoji archivů od 70 . let 20 . století až do současnosti. Připomněli např. význam počátku 90 . let, kdy archivy významně posílily své postavení ve společnosti, protože sehrály klíčovou roli při majetkových restitucích. Následně panelisté diskutovali otázky současnosti archivů a jejich budoucího směřování. Václav Ledvinka připomněl, že menší pozornost je nejen v praxi, ale i v legislativním zázemí věnována specializovaným archivům. Také konstatoval, že bude zřejmě nutné opustit koncept univerzálního archiváře, jenž je schopen spravovat $\mathrm{v}$ rámci archivu všechny fondy. S rozvojem digitálního archivnictví bude nezbytné zavést více specializací, přičemž důsledkem této změny bude odklon od role archiváře coby specialisty věnujícího se profesionálně historickému bádání. Zbývající panelisté zdůraznili význam právní otázky vlastnictví archiválií. $\mathrm{V}$ rámci všeobecné diskuse byla zmíněna obtížnost náboru nových pracovníků. Konkurzy na obsazení míst archivářů bývají často rušeny pro nedostatek vhodných kandidátů.

Pozornost byla dokonce věnována i fyzioterapii v archivní praxi. V rámci sekce, která byla vtipně pojmenována Jak se ve zdraví dožít důchodu, představila Petra Šrámková ze Západočeské univerzity v Plzni hlavní zásady správného (zdravého) sezení u počítače a zvedání těžkých předmětů. Mimořádně hojná účast na této přednášce, zahrnující také praktické pokyny pro archivní každodennost, svědčila o aktuálnosti tohoto tématu.

V rámci sekce Možnosti a limity spolupráce mezi církevními a státními archivy, již moderovaly Jitka Křečková z Národního archivu a Hedvika Kuchařová ze Strahovské knihovny, byla řešena otázka písemností vzniklých z činnosti církví. Akcent byl kladen na aktuální 
problémy, které v této oblasti nastávají, především na vztah původce a vlastníka $\mathrm{k}$ jeho archivu či fyzický stav materiálů.

V první části sekce Elektronická spisová služba - konec archivnictví?, jejímž moderátorem byla Hana Brzobohatá z Moravského zemského archivu v Brně, zazněly referáty zhodnocující uplynulých deset let od uzákonění elektronické spisové služby z pohledu legislativy, dodavatele elektronického systému spisové služby a původce. Sekce následně pokračovala diskuzí o problémech týkajících se výkonu spisové služby v elektronické podobě, s nimiž se archiváři u svých původců setkávají. Jedná se např. o slabé znalosti a nízkou počítačovou gramotnost původců, komplikovanou a často se měnící legislativu či př́iliš složité a uživatelsky nepřívětivé elektronické systémy spisové služby. Obecná shoda zavládla v názoru, že pokud není výkonu spisové služby nakloněno vedení úřadů, nemají ani zaměstnanci motivaci řádně ji vykonávat. Na závěr se však všichni diskutující shodli, že zavedení elektronické spisové služby i přss uvedené problémy rozhodně neznamená konec archivnictví.

Cílem sekce s názvem Archivy a knihovny: Můžeme se inspirovat? bylo představit inspiraci z knihovního prostředí pro archivy. Moderátorem této sekce byl Jan Kaňka z Krajské knihovny Františka Bartoše ve Zlíně. Jednotliví vystupující z řad zaměstnanců knihoven představili ústřední témata, která jsou pro současné knihovnictví klíčová. Jedná se o centralizaci praxe ve smyslu existence jednotných standardů, doporučených postupů i závazného metodického vedení celé sítě knihoven; dále o kooperaci a sdílení mezi knihovnami včetně snahy o zpř́stupnění fondů bez ohledu na vlastnickou instituci. V neposlední řadě byl zmíněn důraz knihoven na interakci s uživateli a na zpř́istupňování analogového i digitálního obsahu. Někteří panelisté upozornili, že prezentované principy spolupráce v rámci knihovní sítě nad rámec legislativních a metodických dokumentů nejsou všeobecně príijímány. V průběhu všeobecné diskuse v této sekci, jež byla poměrně hojně navštívená, zaznělo konstatování, že směřování $k$ centralizaci služeb a sdílení dat je cesta, která je i budoucností archivů. Někteří varovali, že bez této proměny budou archivy v očích veřejnosti ztrácet na významu a kladli důraz na potřebu změny fungování archivů, které by se podle nich měly zaměřit zejména na služby badatelům. Zkušenosti z procesu sdílení služeb a obsahu v knihovnách by podle nich mohly být pro archivy inspirativní. Jako príílad byla uváděna vlna digitalizace matrik, která vzešla zespodu. Někteří z účastníků poukázali na předchozí podobné pokusy a jejich neúspěchy, jež jsou dány odlišným charakterem archivní sítě. Výsledkem diskuse však v této sekci bylo zdưraznění „prouživatelského“ směřování archivů, při kterém je konzervační funkce (včetně získávání archiválií) jen nezbytnou podmínkou. V rámci celé konference byl však tento př́stup spíše minoritní.

Odborný program konference byl doplněn velice bohatými doprovodnými akcemi. Ve volných chvílích mohli účastníci navštívit plzeňská muzea, galerie, divadla, památky a samozřejmě také pivovary. Tak jako na minulých konferencích byl součástí programu i společenský večer s hudebním doprovodem, který vylákal řadu přítomných i $\mathrm{k}$ tanci. U dobrého jídla a pití byla možnost pohovořit se známými kolegy, či se seznámit s novými archiváři a archiváŕkami.

Z hlediska počtu účastníků se jednalo o dosud největší setkání archivářů, které se konalo v České republice, zúčastnilo se ho téměř 500 registrovaných účastníků. Model celostátního setkání archivářù, jenž byl vyzkoušen poprvé v roce 2017 v Liberci, se i během plzeňské konference osvědčil. Vedle tematicky sevřených bloků souvisejících s místem konání 
přinesla konference aktuální reflexi stavu proměňujícího se tradičního oboru, který se více než kdy jindy pohybuje na křehkých styčných plochách dlouhodobé péče o historické dokumenty, historiografie a moderní veřejné správy. Velkým př́ínosem oproti minulým ročníkům jsou videozáznamy ze všech sekcí, které jsou dostupné na stránkách Státního oblastního archivu v Plzni. ${ }^{2}$ Závěrem nezbývá než konstatovat, že v pořadí již 18. celostátní archivní konference byla po všech stránkách velice zdařilým setkáním, za což organizátorům patří velký dík a uznání. Už nyní se můžeme těšit na další ročník, který se uskuteční v roce 2021 v Pardubicích a jehož hlavním partnerem bude Státní oblastní archiv v Zámrsku.

Marek Brčák - Petr Cajthaml-Marek Ďurčanský - Roman Elner - Eliška Pavlásková - Lenka Vašková - Zdeněk Vašek doi: $10.14712 / 23365730.2020 .5$

2 Viz http://www.soaplzen.cz/node/884 (nahlíženo dne 6. 12. 2019). 